From the Department of Animal Husbandry and Genetics, Norwegian College of Veterinary Medicine, Oslo, Norway.

\title{
Factors Related to Dairy Herds with a High and Low Incidence of Ketosis
}

\author{
By Egil Simensen, Per Gillund, Bjørn Lutnoes, Olav Alstad and Karl Halse
}

\begin{abstract}
Simensen, E., P. Gillund, B. Lutnæs, O. Alstad and K. Halse: Factors related to dairy herds with a high and low incidence of ketosis. Acta vet. scand. 1988, 29, 377-383. - Factors associated with the incidence of ketosis were studied in 10 herds with a high incidence of the condition (H herds) and 12 herds with a low incidence, ( $\mathrm{L}$ herds), based on available production data and one-day recordings undertaken once in each herd.

Annual milk yield was at the same level in $\mathrm{H}$ and $\mathrm{L}$ herds. Fat-corrected (4\% standard) maximum daily milk yield was significantly lower, and the corresponding $\%$ milk fat significantly higher, in the $\mathrm{H}$ herds. Feeding control showed that about one fattening feed unit more of roughages was fed per cow per day in the $\mathrm{L}$ herds, in which the roughage diet was also more varied.

In the $\mathrm{H}$ herds, plasma acetoacetate and free fatty acid levels were higher 2-30 and 31-60 days after calving, whereas plasma glucose levels were lower 2-30 days after calving. The acetoacetate level in morning milk and in blood plasma before feeding were significantly correlated $(r=0.971)$. The estimated energy balance for cows 2-60 days after calving was at the same level in both herd categories.

The study design used did not appear to be suited for revealing causal factors as a basis for preventive action in herds with a high incidence of ketosis.
\end{abstract}

acetoacetate; free fatty acids; glucose; milk yield; milk fat; feeding control; energy balance; early lactation; dairy cows.

\section{Introduction}

While some herds remain free from ketosis, there are also "problem " herds with high incidence rates (Simensen et al. 1987 a). As energy supply in relation to milk yield in early lactation is considered an important etiological factor (Dale et al. 1978, Halse 1982), feeding should be evaluaed in the latter ("problem«) group of herds in order to reveal underlying causal factors. Plasma levels of acetoacetate, glucose and free fatty acids, and percentage milk fat and milk acetoacetate content, are relevant parameters in this respect (Hove \& Halse 1983).
The present study was undertaken to evaluate possible factors characterizing herds with a high incidence of ketosis by means of available production data and herd investigations which are feasible under practical field conditions.

\section{Materials and methods \\ Study design}

The study was carried out in 22 herds participating in the national Milk Recording Scheme in the district of Tynset/Alvdal in NordØsterdalen, in October/November 1983. Nord-Østerdalen is a mountain valley dis- 
trict with a generally high incidence of ketosis (Simensen et al. 1987 a). The herds were considered to be representative of dairy herds in the district, with an average size of 17 cows. Most calvings took place in early autumn.

The study was designed to include a group of herds with a high incidence of ketosis ( $\mathrm{H}$ herds), and another group with a low incidence (L herds). Selection was carried out on the basis of records showing herd incidence rates during the period September 1982-August 1983. An incidence rate of more than $25 \%$ was used as a criterion of $\mathrm{H}$ herds, and below $25 \%$ as a criterion of L herds. Eleven herds in each category were selected.

A final grouping of the 22 herds was carried out on the basis of the occurrence of ketosis during the period September 1983-August 1984. During this period, the incidence rate in 2 of the previous $\mathrm{H}$ herds fell to below $25 \%$, whereas that in 1 of the previous L herds rose to above $25 \%$. The present material thus includes $10 \mathrm{H}$ herds and $12 \mathrm{~L}$ herds.

\section{Disease and production data}

Veterinary treatment for ketosis, as recorded in the individual health cards (Solbu 1983), was used as criterion for ketosis. When veterinary treatment was recorded in the health cards, the results of the test for ketone bodies in milk by means of the nitroprusside reaction (Ketotest ${ }^{(8)}$ ) was also noted. These data were obtained from records kept at the local office of the Milk Recording Scheme.

The annual statistics from the Milk Recording Scheme for 1983, together with the monthly reports for August-December 1983, provided production data. Information regarding the use of concentrates around calving and the first 3 weeks of lactation, was obtained by interviews.

\section{Herd investigations}

The herd investigations were designed as one-day recordings undertaken once per herd. Data originated from milk control, feeding control, and blood collection for determination of plasma acetoacetate, glucose and free fatty acids. Further samples were taken for the determination of acetoacetate in milk. Chest girth was recorded.

Milk control included weighing in the afternoon and the next morning. Samples were taken for determination of \% milk fat (pooled samples of morning and afternoon milk). Feeding control has been described previously (Simensen et al. 1987 b).

Energy balance in terms of fattening feed units (FFU) for individual cows was calculated. Energy requirement for maintenance was based on chest girth recordings for estimation of live weight, and energy requirement for production was based on fat-corrected ( $4 \%$ standard) milk yield on the day of recording. Energy supply was based on herd average figures for roughages, together with the individual amounts of concentrates which were supplied.

Blood samples were taken in the morning, before first feeding. Samples for determination of milk acetoacetate were taken from the morning milk. Immediately after collection, blood and milk samples were placed in ice water. The blood was centrifuged within $2 \mathrm{~h}$ of collection, and plasma and milk samples were stored in liquid nitrogen.

\section{Analytical methods}

Levels of acetoacetate in plasma and milk were determined by the method of Blom \& Halse (1975). Free fatty acids were quantified enzymatically in a GEMSAC fast analyser (Reagents kit from Wako Chemicals, GMBH). Plasma glucose was determined in a Technicon Auto-Analyser II according to 
an enzymatic method described by the instrument manufacturer.

Associations between various factors were statistically evaluated by means of Student's $t$ test and simple linear regression analysis.

As a measure of the occurrence of ketosis, the term lactational incidence rate is used. It is defined as the number of cows with at least one occurrence of ketosis during a lactation divided by the number of cows at risk for the lactation, expressed as a percentage (Dohoo et al. 1983).

\section{Results}

\section{Calving season and incidence of ketosis}

The start of the calving season in the herds studied varied from the second half of August to the first half of September. About $50 \%$ of calvings took place within a period of 30 days, and about $70 \%$ within 60 days. When the herd investigation was carried out in October/November, the average stage of lactation for all cows between 2-60 days after calving was $\mathbf{3 7 . 5}$ days. There was no marked difference between $\mathrm{H}$ herds and $\mathrm{L}$ herds in this respect.

As shown in Table 1, the average lactational incidence rate of ketosis was 3 times higher in the $\mathrm{H}$ herds than in the $\mathrm{L}$ herds. There were also significantly more treatments per cow with ketosis in the $\mathrm{H}$ herds. The highest incidence rate in a single herd was $70 \%$, and none of the herds were free from the disease. $95 \%$ of the recorded treatments were associated with a positive test for ketone bodies in milk. In $66 \%$ of the cases the test score was 2 or 3 (range from 0 , negative to 3 , strongly positive).

\section{Production and feeding}

General production and feeding data are shown in Table 2 . Annual milk yield was almost the same in $\mathrm{H}$ and $\mathrm{L}$ herds, whereas maximum daily milk yield was on average $1.6 \mathrm{~kg}$ lower in the $\mathrm{H}$ herds. The annual average milk fat content was $0.27 \%$ higher in the $\mathrm{H}$ herds, and milk fat corresponding to maximum daily milk yield was $0.18 \%$ higher. The difference between the herd groups as regards fat-corrected $(4 \%)$ maximum daily milk yield and the corresponding $\%$ milk fat, was significant.

Data obtained from the feeding control showed that about 1 FFU more of roughages was consumed per cow per day in the $\mathrm{L}$ herds. The roughage diet was also more varied in these herds. Eight of the $12 \mathrm{~L}$ herds were fed a supplement of root crops, potatoes etc. in addition to grass silage and hay, whereas in only 4 of the $10 \mathrm{H}$ herds were such feedstuffs offered. Based on the interviews,

Table 1. Incidence and treatment rates of ketosis in 10 herds with high $(\mathrm{H})$ and 12 herds with low (L) incidence in Tynset/Alvdal.

\begin{tabular}{|c|c|c|c|c|}
\hline & \multicolumn{4}{|c|}{ Category of herds } \\
\hline & \multicolumn{2}{|c|}{$\mathbf{H}$} & \multicolumn{2}{|c|}{ L } \\
\hline & $\overline{\mathrm{x}}$ & s.d. & $\overline{\mathrm{x}}$ & s.d. \\
\hline No. of cows per herd & 15.5 & 3.5 & 18.5 & 5.1 \\
\hline Lactational incidence rate of ketosis, $\%$ & 40.8 & 14.4 & 13.5 & 4.7 \\
\hline Treatments per cow with ketosis & 2.10 & 0.76 & 1.38 & 0.56 \\
\hline
\end{tabular}

Student's t test for difference between $\mathrm{H}$ and $\mathrm{L}$ :

$\mathrm{p}<0.001$ for lactational incidence rate,

$\mathrm{p}<0.05$ for treatments per cow with ketosis. 
Table 2. Production and feeding data in 10 herds with high $(\mathrm{H})$ and 12 herds with low $(\mathrm{L})$ incidence of ketosis in Tynset/Alvdal.

\begin{tabular}{|c|c|c|c|c|c|}
\hline & \multicolumn{4}{|c|}{ Category of herds } & \multirow{3}{*}{$\begin{array}{l}\text { Test for } \\
\text { difference } \\
\text { between } \mathrm{H} \text { and } \mathrm{L}^{\prime}\end{array}$} \\
\hline & \multicolumn{2}{|c|}{$\mathrm{H}$} & \multicolumn{2}{|r|}{$\mathrm{L}$} & \\
\hline & $\overline{\mathrm{x}}$ & s.d. & $\overline{\mathrm{x}}$ & s.d. & \\
\hline Annual milk yield $(\mathrm{kg})$ & 5894 & 495 & 5973 & 731 & n.s. \\
\hline$\%$ milk fat, annual average & 4.27 & 0.38 & 4.00 & 0.27 & n.s. \\
\hline $4 \%$ fat corrected annual milk yield $(\mathrm{kg})$ & 6039 & 342 & 5920 & 731 & n.s. \\
\hline Maximum daily milk yield $(\mathrm{kg})$ & 24.4 & 1.6 & 25.9 & 2.4 & n.s. \\
\hline$\%$ milk fat corresponding to maximum daily milk yield & 4.01 & 0.39 & 3.83 & 0.15 & $\mathrm{p}<0.01$ \\
\hline $4 \%$ fat corrected maximum daily milk yield $(\mathrm{kg})$ & 24.4 & 1.2 & 25.3 & 2.6 & $\mathrm{p}<0.05$ \\
\hline Test-day amount of roughages per cow (FFU) & 7.4 & 1.5 & 8.4 & 1.4 & n.s. \\
\hline Test-day amount of concentrates per cow (FFU) & 5.7 & 1.3 & 5.7 & 1.9 & n.s. \\
\hline \multicolumn{6}{|l|}{ Concentrates per day, average for the last 3 weeks be- } \\
\hline fore calving $(\mathrm{kg})$ & 1.8 & 0.7 & 1.3 & 0.4 & n.s. \\
\hline Concentrates on the day of calving $(\mathrm{kg})$ & 2.5 & 1.0 & 2.3 & 0.9 & n.s. \\
\hline \multicolumn{6}{|l|}{ Days after calving when full ration of concentrates } \\
\hline first given & 9.9 & 3.0 & 9.4 & 4.2 & n.s. \\
\hline
\end{tabular}

1) Student's t test.

no marked difference between the groups was revealed as regards the use of concentrates around calving, and during the first few weeks of lactation (Table 2).

The average energy balance was positive, and at the same level, in both herd categories (Table 3). The herd distribution of cows 2-60 days after calving is shown in Fig. 1. Generally speaking, energy demand and energy supply were in good accordance in the $\mathrm{H}$ herds, whereas more variation was seen in the $\mathrm{L}$ herds.

\section{Blood and milk parameters}

The results regarding the blood and milk parameters are shown in Table 3. The \% milk fat was higher in the $\mathrm{H}$ herds 2-30 days after calving, though not at the 31-60 days stage. In the $\mathrm{H}$ herds, plasma acetoacetate and free fatty acid levels were higher 2-30 and 31-60 days after calving, whereas plasma glucose levels were lower 2-30 days after calving, as compared to the $\mathrm{L}$ herds.

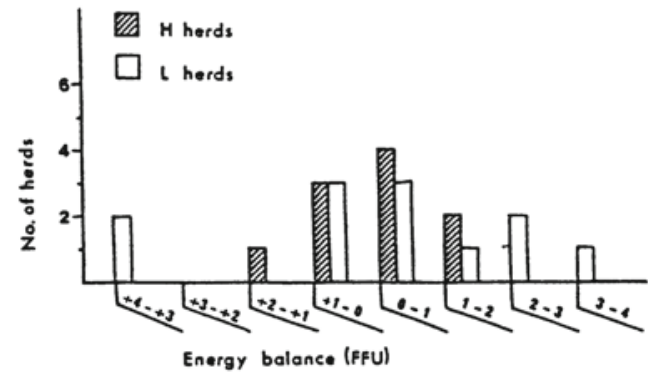

Figure 1. Herd distribution of average energy balance for cows in the period 2-60 days after calving.

There was a highly significant correlation between the level of acetoacetate in plasma and milk, correlation coefficients being: $r$ (Pearson) $=0.971(\mathrm{p}<0.001)$, and $\mathrm{r}$ (Spearman $)=0.888(p<0.001)$. The regression equation was as follows:

$\mathrm{y}=0.008+0.23 \mathrm{x}$

where $y$ is the concentration of acetoacetate in milk, and $x$ the concentration of acetoacetate in plasma (mmol/l).

The distribution of the parameters was skewed, with most of the values at a low level 
Table 3. Energy balance, and blood and milk parameters on the day of recording for cows in different time periods after calving, in 10 herds with high $(\mathrm{H})$ and 12 herds with low $(\mathrm{L})$ incidence of ketosis in Tynset/Alvdal.

\begin{tabular}{|c|c|c|c|c|c|c|c|c|}
\hline & \multicolumn{8}{|c|}{ Days after calving } \\
\hline & \multicolumn{4}{|c|}{$2-30$} & \multicolumn{4}{|c|}{$31-60$} \\
\hline & \multicolumn{2}{|c|}{ H-herds } & \multicolumn{2}{|c|}{ L-herds } & \multicolumn{2}{|c|}{ H-herds } & \multicolumn{2}{|c|}{ L-herds } \\
\hline & $\overline{\mathrm{x}}$ & s.d. & $\overline{\mathrm{x}}$ & s.d. & $\overline{\mathrm{x}}$ & s.d. & $\overline{\mathrm{x}}$ & s.d. \\
\hline Energy balance (FFU) & 0.47 & 1.74 & 0.40 & 2,19 & 0.70 & 1.49 & 0.60 & 1.79 \\
\hline Milk fat $(\%)$ & 4.27 & 0.61 & 4.04 & 0.54 & 3.73 & 0.65 & 3.93 & 0.56 \\
\hline Plasma acetoacetate $(\mathrm{mmol} / \mathrm{l})$ & 3.79 & 7.54 & 1.27 & 1.51 & 1.39 & 2.85 & 0.92 & 2.07 \\
\hline Milk acetoacetate $(\mathrm{mmol} / \mathrm{l})$ & 0.96 & 1.99 & 0.36 & 0.30 & 0.39 & 0.59 & 0.26 & 0.33 \\
\hline Plasma glucose (mmol/l) & 3.33 & 0.59 & 3.57 & 0.38 & 3,68 & 0.45 & 3.66 & 0.40 \\
\hline Plasma free fatty acids (mmol/l) & 556 & 318 & 381 & 264 & 244 & 188 & 224 & 181 \\
\hline Number of cows & 19 & & 36 & & 55 & & 78 & \\
\hline
\end{tabular}

Student's $\mathrm{t}$ test for difference between $\mathrm{H}$ and $\mathrm{L}$ :

2-30 days after calving - plasma acetoacetate, $\mathrm{p}<0.001$

milk acetoacetate, $\quad \mathrm{p}<0.001$

glucose, $\quad \mathrm{p}<0.05$

31-60 days after calving - plasma acetoacetate, $p<0.05$

milk acetoacetate, $\quad \mathrm{p}<0.001$

and few very high observations. According to Halse (1982), $0.06 \mathrm{mmol} / \mathrm{l}$ blood acetoacetate can be considered as the upper limit of a basal, non-ketonemic range, corresponding to about $0.02 \mathrm{mmol} / \mathrm{l}$ in milk. In the period 2-30 days after calving only $29.4 \%$ of the cows in the $\mathrm{H}$ herds showed values below this limit, compared to $48.6 \%$ in the L herds. In the period 31-60 days after calving, values in more than $60 \%$ of the cows in both herd categories were below this limit.

\section{Discussion}

The study demonstrated variations in the incidence of ketosis in herds with seemingly identical feeding regimes and milk yields. No association was found between recorded energy balance and the incidence of ketosis. This result is in contrast to a previous field study (Dale et al. 1978), which revealed an association between underfeeding during early lactation and a high incidence of keto- sis, based on the same principle of one-day feeding control.

The results as shown in Table 3 indicate a lower energy supply in the $\mathrm{H}$ herds. Increased plasma levels of acetoacetate and free fatty acids together with decreased levels of glucose, are frequently associated with a negative energy balance in early lactation (Hove \& Halse 1983). A lower maximum daily milk yield in the $\mathrm{H}$ herds also indicates a lower energy supply in early lactation in these herds.

The difference as indicated above could not be confirmed by the feeding control, as no difference was found between $\mathrm{H}$ and $\mathrm{L}$ herds in average energy balance. In this connection it should be noted that herd averages used in the estimation of roughage consumption may not be sufficiently representative for cows in early lactation, while the susceptiblity to ketosis is at a maximum. It is known that the cow's ability to consume roughages 
increases gradually after calving (Ekern 1972). Furthermore, appetite is generally poor during the first few weeks of lactation (Hellberg 1969). Thus, due to variations in appetite, the energy balances of individual cows may have varied more widely than indicated by the standard deviations in Table 3 . Slow eaters may have been underfed by loosing parts of their concentrate and silage rations to neighbours at the feeding table with a more voracious appetite.

Repeat feeding controls would have given a better estimate of roughage consumption. However, one-day control appeared to be representative, provided the feeding regime is stable (Simensen et al. 1987 b). Better insight would have been gained by recording individual feed intakes, but this would not be feasible under practical field conditions.

In accordance with the results of Øverby et al. (1974), Solbu (1983) and Gröhn et al. (1984), no association was found between the herd incidence rate of ketosis and herd average annual milk yield. The higher $\%$ milk fat in the $\mathrm{H}$ herds is in agreement with previous results which have shown a relationship between the incidence of ketosis and $\%$ milk fat (Øverby et al. 1974, Solbu 1983, Kauppinen 1984, Simensen et al. 1987 a).

On the basis of the earlier results of Dale et al. (1978), particular emphasis has been put on concentrate feeding during the first weeks of lactation in order to provide a sufficient energy supply to prevent ketosis. The results from the present study indicate that roughage feeding is also important. In the L herds somewhat more roughages were fed, and the roughage diet was also more varied. However, differences in roughage consumption can also be related to silage quality and palatibility with effect on the incidence of ketosis. According to Malmstrøm et al. (1987), ketosis can be produced by the feeding of poorly preserved grass silages to cows. Characteristic of such silages seems to be the ability to cause large diurnal variations in plasma ketones and glucose, related to the feeding schedule.

A high correlation was found between prefeeding plasma levels of acetoacetate and the corresponding levels in morning milk. This result is of practical interest, as milk samples for acetoacetate determinations can be readily obtained under field conditions.

\section{References}

Blom $A K$, Halse $K$ : Corticosteroids in nocturnal blood plasma of cows in the field related to stage of lactation and plasma acetoacetate. Acta endocr. 1975, 78, 306-315.

Dale H, Vik-Mo L, Halse $K$ : Ei feltgransking over ketose hjå mjølkekyr sett i høve til energidekninga i tidleg laktasjon. (Ketosis and energy balance in cows during early lactation. A field survey). Norsk Vet.-T. 1978, 90, 3-10.

Dohoo IR, Martin SW, Meek AH, Sandals WCD: Disease, production and culling in holstein-friesian cows. I. The data. Prev. vet. Med. 1983, 1 , 321-334.

Ekern A: Feeding of high yielding dairy cows. III. Roughage intake in high yielding cows when fed grass silage ad libitum. Ås 1972. (Norges landbrukshøgskole, Institutt for husdyrernæring og foringslære). Beretning 149.

Gröhn Y, Thompson JR, Bruss ML: Epidemiology and genetic basis of ketosis in Finnish Ayrshire cattle. Prev. vet. Med. 1984, 3, 65-77.

Halse K: Ketosis research in Norway. In: The Norwegian College of Veterinary Medicine. Publications 1981. Oslo 1982, 5-13.

Hellberg A: Faktorer som påverkar den frivilliga foderkonsumtionen. (Factors influencing voluntary feed consumtion). In: Nötkreatur, Ed.: A. Helmenius. LTs förlag, Stockholm, 1969, 200205.

Hove $K$, Halse $K$ : Energy metabolism in ruminants with special emphasis on ketosis and fertility. Proc. 5th International conference on production disease in farm animals. Uppsala, 1983, 115123. 
Kauppinen $K$ : Annual milk yield and reproductive performance of ketotic and non-ketotic dairy cows. Zbl. Vet. Med. A. 1984, 31, 694-704.

Malmstrøm $P$, Halse $K$, Tveit $B$, Skipnes $P$, Svendsen $M$ : Miljømessige og genetiske årsaker til klinisk og subklinisk ketose. (Environmental and genetic explanation factors for clinical and subclinical ketosis). Norsk Vet. T. 1987, 99, 95-102.

Simensen E, Liestøl K, Svela E: Ketose hos mjølkekyr i Hedmark fylke - epidemiologiske forhold. (Ketosis in Hedmark country - epidemiological relationships). Norsk Vet. T. 1987 a, 99, 103-111.

Simensen E, Alstad $O$, Gillund P, Lutnaes B, Bavre $L$ : Fôrkontroll i mjølkeproduksjonen. (Feeding control in dairy production). Norsk Vet. T. 1987 b, 99, 717-723.

Solbu $H$ : Disease recording in Norwegian dairy cattle. I. Disease incidences and non-genetic effects on mastitis, ketosis and milk fever. Z. Tierzücht. Züchtungsbiol. 1983, 100, 139-157.

Øverby $I$, Aas Hansen $M$, Jonsgärd $K$, Søgnen $E$ : Bovine ketosis. I. Occurrence and incidence in herds affected by ketosis in Eastern Norway 1967-1968. Nord Vet. Med. 1974, 26, 353-361.

\section{Sammendrag}

Problemer $i$ forbindelse med karakteriseringen av melkekubesetninger med høy og lav ketoseinsidens. Undersøkelsen ble gjennomført for å klarlegge muli- ge årsaksfaktorer som grunnlag for forebyggende tiltak i besetninger med mye ketose. Materialet omfatter 10 besetninger med en høy insidens og 12 besetninger med en lav insidens, og bygger pả tilgjengelige produksjonsdata sammen med en-dags registreringer som ble foretatt en gang i hver besetning.

Årlig mjølkeytelse var på samme nivå i de to besetningsgruppene. Fett-korrigert høyeste dagsavdrått var signifikant lavere, og den korresponderende $\%$ mjølkefett var signifikant høyere i $\mathrm{H}$ besetningene. I gjennomsnitt ble det brukt ca. 1 fetningsfôrenhet mer med grovfôr pr. ku pr. dag i besetningene med lite ketose, samtidig som grovfôrrasjonen var mer variert.

I besetningene med høy insidens var plasmakonsentrasjonen av acetoacetat og frie fettsyrer i høyere $\mathrm{i}$ periodene 2-30 og 31-60 dager etter kalving, mens glukoseverdiene var lavere 2-30 dager etter kalving. Energibalansen for enkeltkyr ble beregnet på grunnlag av a) estimert levendevekt og fettkorrigert mjølkemengde på kontrolldagen, og b) gjennomsnittstall når det gjelder opptak av grovfôr, sammen med individuelle tildelte kraftfôrmengder. For kyr i perioden 2-60 dager etter kalving var gjennomsnittlig balanse positiv, og på samme nivå, i de to besetningskategoriene. Registreringsoplegget viste seg ikke á være egnet til klarlegging av årsaksfaktorer som grunnlag for forebyggende tiltak på en tilstrekkelig måte.

(Received February 15, 1988).

Reprints may be requested from: E. Simensen, Norwegian College of Veterinary Medicine, P. O. Box 8146 Dep., N-0033 Oslo 1, Norway. 
